\title{
"Vou tentar ajudar minha família escrevendo essa carta": jogos de gênero em cartas enviadas da Alemanha para o Brasil após a Segunda Guerra Mundial
}

\author{
Méri Frotscher ${ }^{1 ; *}$ \\ ${ }^{1}$ Universidade Estadual do Oeste do Paraná, Cascavel, Paraná, Brasil
}

\section{RESUMO}

O artigo é baseado em cartas enviadas entre 1946 e 1950 da Alemanha à prefeitura municipal de Blumenau (SC), nas quais os remetentes pedem mantimentos, vestuário e intermediação para imigrar, localizar parentes e conhecidos ou iniciar correspondência com habitantes. Neste texto eu discuto a agência exercida por mulheres e homens por meio do envio e redação de cartas-pedido e os “jogos de gênero" presentes na interlocução com o destinatário.

Palavras-chave: cartas; narrativa autobiográfica; agência; jogos de gênero; Alemanha

\section{"I will try to help my family by writing this letter": Gender games in letters sent from Germany to Brazil after World War II}

\section{ABSTRACT}

This article is based on letters sent between 1946 and 1950 from Germany to the town hall of Blumenau - SC, Brazil. In these letters, senders ask for food, clothes and mediation in order to immigrate, to find relatives and acquaintances or to exchange correspondence with inhabitants. In this text, I discuss women and men's agency through writing and sending letters and the "gender games" present in the interlocution with the adressee. Key-words: letters; autobiographic narratives; agency; gender games; Germany

DOI: http://dx.doi.org/10.1590/2237-101X02004006

* Professora da Universidade Estadual do Oeste do Paraná/Departamento de História, Programa de Pós-graduação em História, Marechal Cândido Rondon/PR — Brasil. E-mail: merikramer@hotmail.com. https:// orcid.org/0000-0003-0172-4126.

A pesquisa que resultou neste artigo contou com financiamento do CNPq (Bolsa de Produtividade). Agradeço aos historiadores Vanderlei Machado e Marcos Nestor Stein pela leitura crítica e sugestóes para o aprimoramento do texto. 
"VOU TENTAR AJUdAR MINHA FAMÍlIA ESCREVENDO ESSA CARTA": JOGOS DE GÊNERO EM CARTAS enviadas da Alemanha para o Brasil após a Segunda Guerra Mundial

Méri Frotscher

\section{"Voy intentar ayudar mi familia escribiendo esa carta": juegos de género en cartas enviadas de Alemania para Brasil después de la Segunda Guerra Mundial}

\section{RESUMEN}

El artículo está basado en cartas enviadas entre 1946 y 1950 de Alemania a la Prefectura Municipal de Blumenau - SC, en las cuales los remitentes piden mantenimiento, vestuarios e intermediarios para inmigrar, localizar parientes y conocidos o iniciar correspondencia con los habitantes. En este texto, discuto la exigencia ejercida por mujeres y hombres por medio del envío y redacción de cartas-pedido y los "juegos de género" presentes en la interlocución con el destinatario.

Palabras clave: Cartas; Narrativa Autobiográfica; Agencia; Juegos de Género; Alemania.

Uma mulher, mãe de três crianças, lhe apela e lhe pede ajuda. O senhor deve estar admirado, senhor prefeito, por eu me dirigir exatamente ao senhor. No meu tempo de escola eu tive uma colega de classe que se mudou para o Sul do Brasil e, justamente, para Blumenau. Eu pude guardar bem o nome da cidade. Então me surgiu a ideia de enviar uma carta-pedido ao senhor prefeito, a mais alta instância de Blumenau. Nós não temos nem conhecidos, nem parentes no além-mar. A miséria é grande e estamos à beira do desespero. ${ }^{1}$

Com este preâmbulo, Karoline S., moradora da regiáo industrial do Ruhr, Alemanha, inicia sua carta endereçada em 1947 ao prefeito do município de Blumenau (SC), Sul do Brasil, para pedir mantimentos. A escrita e o envio de uma carta a uma autoridade desconhecida no exterior são o recurso utilizado por esta mulher para tentar atenuar a carestia vivida por ela e sua família.

Nas linhas a seguir, irei explorar cartas-pedido (Bittfriefe, em alemão) tais como a de Karoline, escritas por homens e mulheres e enviadas da Alemanha para a prefeitura de Blumenau nos anos seguintes ao término da Segunda Guerra Mundial. O intuito é apreender os "jogos de gênero" nelas presentes. Utilizo tal noção com base na formulação do historiador Luc Capdevila, que entende por "jogos de gênero" as estratégias de ação baseadas em

\footnotetext{
${ }^{1}$ Todas as citaçôes de fontes e obras de autores em língua estrangeira foram traduzidas pela autora. "Eine Frau, Mutter von 3 Kindern ruft Sie an und bittet um Ihre Hilfe. Sie werden erstaunt sein, Herr Bürgermeister, da $\beta$ ich mich gerade an Sie wende. Zu meiner Schulzeit hatte ich eine Schulkammeradin die nach Südbrasilien und gerade nach Blumenau verzog. Den Namen der Stadt konnte ich gut behalten. Da bin ich denn auf den Gedanken gekommen, an Sie Herr Bürgermeister die höchste Instanz von Blumenau einen Bittbrief zu senden. Wir haben weder Bekannte noch Verwandte in Übersee. Die Not ist groß und wir sind der Verzweiflung nahe." Carta de Karoline S. Wuppertal-Elberfeld, 9 abr. 1947. Acervo ND.
} 
"VOU TENTAR AJUdAR MINHA FAMÍlIA ESCREVENDO ESSA CARTA": JOGOS DE GÊNERO EM CARTAS enviadas da Alemanha para o Brasil após a Segunda Guerra Mundial

\section{Méri Frotscher}

modelos socialmente aceitos para a atuação feminina ou para a ação masculina. ${ }^{2} \mathrm{Ou}$ seja, buscamos perceber como os remetentes, na construção de suas cartas-pedido e na tentativa de sensibilizar o destinatário, “jogam com expectativas sociais a respeito do que é próprio do masculino e do feminino, de homens e de mulheres" ${ }^{3}$

Com base nas cartas busco também apreender as relações de gênero estabelecidas na interlocução com o destinatário, já que tais fontes são "testemunhos de redes de comunicação". ${ }^{4}$ Como sublinhou o filósofo Michel Foucault, a carta proporciona um face a face, pois "é simultaneamente um olhar que se volve para o destinatário (por meio da missiva que recebe, ele sente-se olhado) e uma maneira de o remetente se oferecer ao seu olhar pelo que de si mesmo lhe diz". motivos, tais cartas apresentam a possibilidade de uma abordagem a partir da perspectiva dos estudos de gênero, categoria compreendida, conforme formulou a historiadora Joan Scott, como "um elemento constitutivo de relaçóes sociais baseadas nas diferenças percebidas entre os sexos" e "uma forma primária de dar significado às relaçôes de poder". 6

As cartas aqui submetidas à análise são entendidas não apenas enquanto fontes históricas, mas enquanto práticas de escrita de pessoas "comuns" que procuravam reconstruir suas vidas numa Alemanha em ruínas, onde se reconfiguravam feminilidades e masculinidades. Por serem "escritas de si”, são compreendidas enquanto narrativas autorreferenciais nas quais aquele que escreve é "personagem de si mesmo", num "teatro de memórias" ambientado num país derrotado não apenas militarmente, mas também moralmente. Numa "escrita de si", "[...] o indivíduo assume uma posição reflexiva em relação à sua história e ao mundo onde se movimenta". ${ }^{8}$ Isso não significa dizer, como lembra a historiadora Michelle Perrot, que as cartas têm um conteúdo espontâneo e transparente e que sejam reveladoras do self: "Não há nada menos espontâneo do que uma carta, nada menos transparente do que uma autobiografia, feita para ocultar tanto quanto para revelar. Mas essas sutis manipulaçóes do esconder/mostrar nos levam, pelo menos, à entrada da fortaleza".

As fontes utilizadas fazem parte de um conjunto maior de cartas preservadas, formado por quatro dezenas de missivas enviadas àquela prefeitura, a maioria com o pedido de do-

\footnotetext{
${ }^{2}$ CAPDEVILA, Luc. Résistance civile et jeux de genre. France-Allemagne-Bolivie-Argentine. Deuxième Guerre monciale - années 1970-1980. Annales de Bretagne et de Pays de l'Quest, t. 108, n. 2, p. 103-128, 2001.

${ }^{3}$ PEDRO, Joana Maria; PEREIRA, Silvana Maria; VENSON, Anamaria Marcon. Para além das áreas do conhecimento definidas: relaçôes de gênero e interdisciplinaridade. In: CRESCÊNCIO, Cíntia Lima; SILVA, Janine Gomes da; Lídia Schneider Bristot (Org.). Histórias de gênero. São Paulo: Verona, 2017, p. 26. ${ }^{4}$ MALATIAN, Teresa. Cartas. Narrador, registro e arquivo. In: PINSKY, Carla B.; LUCA, Tania R. de (Org.). O historiador e suas fontes. São Paulo: Contexto, 2011, p. 203.

${ }^{5}$ FOUCAULT, Michel. A escrita de si. In: O que é um autor? Lisboa: Passagens, 1992, p. 156.

${ }^{6}$ SCOTT, Joan. Gênero: uma categoria útil de análise histórica. Educação e Realidade, Porto Alegre, v. 20, n. 2, 1995, p. 86.

${ }^{7}$ GOMES, Angela de Castro (Org.). Escrita de si, escrita da história. Rio de Janeiro: Editora FGV, 2004, p. 17.

${ }^{8}$ MALATIAN, Teresa. Cartas. Narrador, registro e arquivo, op. cit., p. 195.

9 PERROT, Michelle. Introdução. In: (Org.). História da vida privada. Da Revolução Francesa à Primeira Guerra. São Paulo: Companhia das Letras, 1991, v. 4, p. 11.
} 
"VOU TENTAR AJUdAR MINHA FAMÍlIA ESCREVENDO ESSA CARTA": JOGOS DE GÊNERO EM CARTAS enviadas da Alemanha para o Brasil após a Segunda Guerra Mundial

\section{Méri Frotscher}

nativos. ${ }^{10}$ São mencionados Liebesgaben ou Carepackete, em alemão, ou CARE package, em inglês. ${ }^{11}$ As cartas foram redigidas entre 1946 e 1950, período entre a liberação da correspondência com o Brasil e o início da Guerra Fria, quando a Alemanha havia sido dividida para administração pelo Comando Militar Aliado. São cartas escritas tanto por pessoas que não dispunham mais dos endereços de parentes ou conhecidos que moravam no município como por pessoas que não tinham contato algum. Os ofícios-resposta da prefeitura não fazem parte do conjunto documental preservado.

Sabe-se que moradores de Blumenau enviaram pacotes de mantimentos diretamente a parentes e conhecidos que moravam na Alemanha, movidos pelos pedidos e pela campanha humanitária internacional em ajuda à Europa. As cartas as quais tive acesso provavelmente foram preservadas e reunidas por terem sido enviadas náo a particulares, mas à prefeitura municipal, por remetentes que não tinham contatos na cidade ou não tinham mais os endereços de familiares distantes e conhecidos.

Por meio de uma das cartas o leitor toma conhecimento de que houve um incentivo das autoridades na Alemanha para que os habitantes recorressem à ajuda no exterior. Segundo uma remetente, que escreveu durante a primavera de 1946: "Passou um comunicado pela imprensa alemã informando que aqueles que tivessem parentes ou amigos no exterior poderiam se comunicar com eles para que mandassem mantimentos." ${ }^{\prime 2}$ Sabe-se que o restabelecimento do serviço postal com o exterior e o envio de CARE packages, sobretudo dos Estados Unidos, incentivou a redação de cartas-pedido também para o Brasil. No Sul do Brasil chegou-se a organizar após a guerra o Comitê de Socorro à Europa Faminta, que atuou entre 1946 e 1949 e enviou pacotes de mantimentos também à Alemanha. ${ }^{13}$

Das 41 cartas utilizadas para a análise, 27 foram escritas por homens, 13 por mulheres e uma foi assinada em nome da família. A grande maioria das missivas, 38 de 41, foi escrita integralmente na língua alemã, sendo que duas foram escritas na língua inglesa e uma, parte em inglês, parte em alemão. Todas as três cartas em que se usa a língua inglesa foram enviadas por mulheres da zona britânica de ocupação da Alemanha.

A maioria dos remetentes pede donativos (mantimentos e vestuário), mas também há os que solicitam a intermediação da prefeitura para a obtenção de empregos e ajuda para imi-

\footnotetext{
${ }^{10}$ As cartas foram localizadas pela autora em 2010 no acervo documental em posse de Niels Deeke, advogado aposentado, filho de Hercílio Deeke, prefeito de Blumenau nas gestôes de 1951-1956 e 1961-1966. Os períodos das gestóes não coincidem com a datação das cartas aqui analisadas. Nas referências às cartas citadas, a localização dessa coleção será doravante mencionada como "Acervo ND".

${ }^{11}$ Os assim chamados CARE package eram pacotes de mantimentos enviados à Europa depois do final da II Guerra Mundial pela organização humanitária norte-americana CARE - Cooperative for Assistance and Relief Everywhere.

${ }^{12}$ Carta de Elfriede P. Hamburg, 25 maio 1946. Acervo ND.

${ }^{13}$ Sobre isto vide dissertação de mestrado de FERNANDES, Evandro. S.O.S. Europa faminta: Comitê de Socorro à Europa Faminta - SEF e artigo do mesmo autor: Organização e articulação do Comitê de Socorro à Europa Faminta — SEF (1946-1949). História Unisinos, v. 17, n. 2, p. 97-111, 2013.
} 
"VOU TENTAR AJUdAR MINHA FAMÍlIA ESCREVENDO ESSA CARTA": JOGOS DE GÊNERO EM CARTAS enviadas da Alemanha para o Brasil após a Segunda Guerra Mundial

\section{Méri Frotscher}

grarem $^{14}$ ou endereços de parentes, conhecidos ou de desconhecidos para iniciarem correspondência. Levo em conta não apenas a forma e o conteúdo, mas o próprio gesto de escrever e enviar uma carta-pedido, endereçada a autoridade desconhecida no exterior, como um exercício de agência e, ao mesmo tempo, de performatividade. ${ }^{15}$ A agência, como entende Saba Mahmood, é um "processo que não só assegura a subordinação do sujeito às relações de poder, mas também produz os meios através dos quais ele se transforma numa entidade autoconsciente e agente" ${ }^{16}$ Busco perceber, nas linhas seguintes, como se exerce essa agência na própria estruturação e forma da narrativa das cartas.

\section{"Uma mulher, mãe de 3 crianças lhe apela e pede ajuda"}

Muito embora os(as) remetentes sejam homens e mulheres de diferentes classes sociais, ocupações, gerações, níveis de instrução, todas as cartas são dirigidas a um homem do poder público, autoridade máxima de uma cidade no exterior, por muitos reconhecida como uma ex-colônia de imigração alemá, da qual se espera solidariedade e ajuda. A interlocuçáo com esse destinatário masculino é permeada também pela referência e identificação com modelos socialmente aceitos para a atuação feminina ou masculina e para o exercício do papel de mãe ou pai. $\mathrm{O}$ próprio fato de todos os remetentes pressuporem que o prefeito fosse do sexo masculino é indício de uma cultura política que naturalizava a ocupação de tal cargo público por homens.

A forma como essa relação é permeada por questões de gênero pode ser visualizada na carta de Karoline S., que aparece no preâmbulo deste texto. Ali, a remetente atribui certos papéis sociais e de gênero tanto para si própria como para o destinatário. Karoline inicia sua carta apresentando-se como "uma mãe de três filhos" "à beira do desespero". ${ }^{17}$ A maternidade é o meio pelo qual ela se autoidentifica na carta. $\mathrm{O}$ motivo de apelar àquela autoridade - "a mais superior instância de Blumenau”, como ela própria a descreve — é a circunstância emergencial. Sua família havia perdido tudo em um bombardeio ocorrido em 1943. ${ }^{18}$ Na sequência, Karoline refere-se ao internamento da filha de 20 anos com diagnós-

\footnotetext{
${ }^{14}$ Uma análise sobre os pedidos de emprego e ajuda para imigrar ao Brasil, presentes no mesmo conjunto documental, foi realizada em outro artigo: FROTSCHER, Méri. "Uma cinzenta falta de esperança paira sobre todos nós": Uma análise de cartas de mulheres e homens com intenção de emigrar da Alemanha para o Brasil (1946-1950). Revista de História, São Paulo, n. 117, p. 1-38, 2018. Disponível em: <http://www.revistas.usp. $\mathrm{br} /$ revhistoria/article/view/138467/139822>.

${ }^{15}$ Para uma discussão sobre a noção de performatividade, em conexão com a prática epistolar privada, vide LIMA, Kleverson Teodoro de. Cartas, história e linguagem. Revista de Teoria da História, ano 1, n. 3, p. 210-225, jun. 2010.

${ }^{16}$ MAHMOOD, Saba. Teoria feminista, agência e sujeito liberatório. Algumas reflexóes sobre o revivalismo islâmico no Egipto. Etnográfica, v. 10, n. 1, 2006, p. 121.

${ }^{17}$ Carta de Karoline S. Wuppertal-Elberfeld, 9 abr. 1947. Acervo ND.

${ }^{18}$ Durante toda a guerra os bombardeios destruíram aproximadamente $38 \%$ da área construída de Wuppertal,
} 
"VOU TENTAR AJUdAR MINHA FAMÍlIA ESCREVENDO ESSA CARTA": JOGOS DE GÊNERO EM CARTAS enviadas da Alemanha para o Brasil após a Segunda Guerra Mundial

\section{Méri Frotscher}

tico de desnutrição e pede o envio de mantimentos. Ela chega a especificá-los e a indicar as respectivas quantidades desejadas, demonstrando objetividade e reforçando a seriedade do pedido. Citados são carne, peixe, açúcar, gordura, geleia e queijo. Na sequência ainda pede roupas e calçados para o filho de 7 anos. Assim, ela se coloca como responsável e preocupada com a alimentação, o vestuário e a saúde dos filhos.

Segundo as sociólogas Sybille Meyer e Eva Schulze, sobretudo a partir de 1943, devido à guerra aérea (Luftkrieg), recaíam sobre as mulheres alemãs cada vez mais novas tarefas e exigências. A sobrecarga de trabalho e as dificuldades a serem superadas na vida cotidiana se intensificaram. Tais exigências não diminuíram depois da guerra, quando os perigos relativos à saúde de familiares, por meio da desnutriçấo e de doenças, aumentaram. ${ }^{19}$

Noutra parte da carta de Karoline, a remetente procura justificar seu pedido de mantimentos e obter a solidariedade do remetente por meio da associação entre gênero e papéis sociais socialmente aceitos: "Prezado senhor prefeito, o senhor certamente também tem uma esposa e filhos [...]." ${ }^{20}$ Aqui aparece a pressuposição de que uma autoridade política, tal como o destinatário, certamente também teria família própria constituída. Assim, enquanto esposo e pai, ele teria determinados papéis sociais a cumprir, como o de provedor da família. Esse papel social, no caso do prefeito, se acumulava à sua função de gestor político e administrativo do município, à qual a remetente implicitamente associa a tarefa de zelar pela assistência social.

Apesar da referência à suposta situação familiar do destinatário, ou seja, a um aspecto da vida privada, a relação intersubjetiva que a remetente procura estabelecer parte do respeito e reconhecimento dele enquanto autoridade pública. Por isso, ao final da missiva, Karoline expressa preocupação com a forma pela qual a carta poderia ser recebida. Aqui novamente questôes de gênero permeiam a narrativa. Ela mais uma vez mobiliza uma atribuiçáo positiva associada à figura da mãe:

Por favor, leve a sério este pedido, é uma chamada de emergência. Quando, enquanto mãe, se é obrigada a ver como crianças passam fome, então o senhor pode entender minha carta-pedido. Se meu pedido for atendido, o senhor terá feito cinco pessoas felizes. A felicidade seria imensa. Mas se essa carta for parar na lixeira, peço-lhe desculpas. Que o querido Deus proteja o senhor e sua família em sua vida. ${ }^{21}$

localizada na região industrializada do Ruhr. Disponível em: <https://de.wikipedia.org/wiki/Wuppertal>. Acesso: 20 jun. 2017.

${ }^{19}$ MEYER, Sibylle; SCHULZE, Eva. "Als wir wieder zusammen waren, ging der Krieg im Kleinen weiter". Frauen, Männer umd Familien in Berlin der vierziger Jahre. In: NIETHAMMER, Lutz; PLATO, Alexander von. "Wir kriegen jetzt andere Zeiten". Auf der Suche nach der Erfahrung des Volkes in nachfaschistischen Ländern. Berlim/Bonn: Verlag J. H. W. Dietz, 1985, p. 308.

20 "Sehr geehrter Herr Bürgermeister, Sie haben doch sicher auch eine Frau und Kinder [...]." Carta de Karoline S. Wuppertal-Elberfeld, 9 abr. 1947. Acervo ND.

21 "Nehmen Sie diese Bitte nicht so leicht es ist ein Notruf. Wenn man als Mutter zusehen muß wie Kinder 
"VOU TENTAR AJUdAR MINHA FAMÍlIA ESCREVENDO ESSA CARTA": JOGOS DE GÊNERO EM CARTAS enviadas da Alemanha para o Brasil após a Segunda Guerra Mundial

\section{Méri Frotscher}

Karoline constrói uma narrativa na qual assume um atributo cultural e socialmente associado às mães enquanto responsáveis pelo cuidado da família e, ao mesmo tempo, "joga” com esse papel na relação intersubjetiva que estabelece com um destinatário masculino, que ela supóe ser esposo e pai. Dessa maneira ela justifica e imprime um sentido digno ao seu pedido.

Quanto ao esposo e pai das crianças da própria remetente, este não é mencionado explicitamente na carta. Sua presença na família fica apenas implícita na narrativa, quando Karoline se refere às cinco pessoas que ficariam contentes, caso o pedido fosse atendido (na carta são mencionados os três filhos). A invisibilidade do marido na narrativa e o fato da remetente ter assinado a carta sozinha demonstram a sua agência. A não menção explícita do marido - impossível saber se foi ato proposital ou inconsciente - acaba por reforçar a imagem desta "mãe de três filhos", zelosa e responsável, que procurava todos os meios para suprir as necessidades mais básicas da família.

Nas famílias alemãs nas quais os pais/maridos estavam ausentes durante a guerra, as mulheres tiveram que assumir "tanto o papel da educação, quanto o do abastecimento" dos familiares. ${ }^{22}$ Essas funçôes cabiam também a elas, no imediato pós-guerra, em razão das mudanças conjunturais ocasionadas pela guerra, tais como viuvez, maridos amputados, psicologicamente afetados, prisioneiros de guerra, entre outros motivos. Algumas cartas de mulheres alemãs das quais dispomos mostram como, ainda em 1948, continuavam sobrecarregadas com tais tarefas. Por meio das cartas, elas recorreram à ajuda, em nome da família, não somente quando estavam sem os maridos — na condição de viúvas, separadas ou esperando notícias deles, estando eles desaparecidos, já mortos ou na condição de prisioneiros de guerra - mas também quando eles (já) estavam em casa.

Este é o caso de Magda G., cujo marido, feito prisioneiro de guerra pelos russos, havia recém-retornado para casa. Magda escreve todo o texto na primeira pessoa do plural e assina a carta acrescentando também os nomes do marido e das duas filhas. Este procedimento difere do tomado pelas outras cinco mulheres - incluindo Karoline, citada anteriormente, - que sabemos terem sido casadas.

Em sua carta, Magda informa a condição de refugiados de guerra e mostra a preocupação dela e do marido com a saúde das filhas, em razão da carência de alimentação:

Depois de muito pensar, decidi submeter este pedido ao senhor. Nós fomos expulsos de nossa pátria na Alta Silésia e moramos aqui na Baviera em circunstâncias nada invejáveis. Somos uma família de quatro pessoas e moramos num quarto. Faltam todas as coisas necessárias, principalmente roupas e material escolar. Há algumas semanas se percebe, principalmente, falta de comida. Temos que, cada vez mais, apertar os cintos, mas não dá para apertá-los mais.

hungern so können Sie meinen Bittbrief verstehen. Sollte meine Bitte erhört werden, so hätten Sie 5 Menschen glücklich gemacht. Die Freude wäre nicht auszudenken. Wenn dieser Brief ungeachtet in den Papierkorb wandert, so bitte ich um Entschuldigung, Möge der lieber Gott Sie und Ihre Familie in Ihrem Leben schützen." Carta de Karoline S. Wuppertal-Elberfeld, 9 abr. 1947. Acervo ND. Na transcrição das cartas foi respeitada a escrita dos remetentes, como neste trecho, onde falta pontuação em algumas frases.

${ }^{22}$ PLATO, Alexander von; LEH, Almut. "Ein unglaublicher Frühling”: Erfahrene Geschichte im Nachkriegsdeutschland 1945-1948. Bonn: Bundeszentrale für politische Bildung, 1997, p. 47. 
"VOU TENTAR AJUdAR MINHA FAMÍLIA ESCREVENDO ESSA CARTA": JOGOS DE GÊNERO EM CARTAS enviadas da Alemanha para o Brasil após a Segunda Guerra Mundial

\section{Méri Frotscher}

Nós temos duas crianças em idade escolar (meninas) de 9 e 11 anos e estamos preocupados especialmente com o desenvolvimento delas. ${ }^{23}$

A autora sublinha o fato de os quatro membros da família habitarem um único quarto. A carta segue com o pedido de um pacote de mantimentos, "mesmo que pequeno". Ela mobiliza também o atributo de mãe provedora, responsável pela educação, saúde e alimentação, junto com o marido. É mais em função das filhas, mencionadas no diminutivo, que o pedido é elaborado: "Mesmo que seja pouco, para as nossas criancinhas isso significa um complemento muito bem-vindo para a manutenção da saúde nessa época difícil, a mais difícil que enfrentamos, em termos de alimentação." ${ }^{24}$ Aqui também, como no caso de Karoline, a remetente se coloca enquanto responsável pela alimentação da família.

A situação vivida pela família de Magda, mesmo com o retorno do marido, era preocupante. A guerra e suas consequências teriam acarretado não apenas carência material, mas também frustração e resignação ao casal, como se pode perceber neste trecho: "Nós não gostamos de escrever demais. A miséria pela qual tivemos que passar nos últimos anos nos emudeceu. Faz pouco tempo que meu marido, prisioneiro de guerra dos russos, retornou para casa." 25 Magda é a única mulher que menciona que o marido foi soldado durante a guerra. Entretanto, ou talvez exatamente por isso, não acrescenta mais nenhuma informação a respeito. A palavra que melhor parece traduzir o trecho acima citado, no qual ela se refere à "miséria” vivida durante e logo após a guerra, é emudecimento.

Segundo o historiador Berndt Wendt, durante o nazismo, foi dada à mãe uma funçáo especial enquanto mantenedora e reprodutora da chamada "völkische Substanz" ("substância nacional e racial"). Negar-se a ter filhos ou a esterilidade eram reconhecidos motivos para o marido pedir o divórcio. Mas, como acentua Wendt, os nazistas nunca chegaram a formular uma ideologia e uma política uniforme e clara para a mulher e a família alemãs. Também se observam contradiçóes entre uma pretensão ideológica e uma realidade social de um moderno estado industrial pressionado pela economia de guerra. ${ }^{26}$

\footnotetext{
23 "Nach langem Überlegen habe ich mich entschlossen, Ihnen eine Bitte zu unterbreiten.

Wir sind aus unserer Heimat in Oberschlesien ausgewiesen worden und leben hier in Bayern in keinem beneidenswerten Zustande. Wir sind eine Familie von 4 Personen und leben in einem Zimmer. Es fehlen an allen notwendigen Sachen, besonders an Kleidung und Schulwerk. Seit einigem Wochen macht sich besonders der Mangel an Lebensmitteln bemerkbar. Wir müssen unseren Leibriemen immer enger schnallen, aber weiter geht es nicht mehr. Wir haben 2 schulpflichttige Kinder (Mädchen) von 9 und 11 Jahren und sind besonders an deren Entwicklung besorgt." [grifo no original] Carta de Magda Gruner. Murnau, 20 jul. 1947. Acervo ND. 24 "Wenn es noch so klein wäre, für unsere Kinderchen bedeutet dies ein willkommenen Zusatz in der Gesunderhaltung in dieser schweren Zeit, in der schwersten Zeit für uns die wir ernährungsmäßig durchmachen." Carta de Magda G. Murnau, 20 jul. 1947. Acervo ND.

25 "Wir lieben nicht, zu viel Worte zu machen. Die viele Not, die wir in den letzten Jahren durchmachen mußten, hat uns stumm gemacht. Mein Mann ist vor kurzem aus der Gefangenschaft (russischen) zurückgekehrt." Carta de Magda G. Murnau, 20 jul. 1947. Acervo ND.

${ }^{26}$ WENDT, Bernd Jürgen. Das nationalsozialistische Deutschland. Berlim: Landeszentrale für politische Bildungsarbeit Berlin, 1999, p. 67-69.
} 
"VOU TENTAR AJUdAR MINHA FAMÍlIA ESCREVENDO ESSA CARTA": JOGOS DE GÊNERO EM CARTAS enviadas da Alemanha para o Brasil após a Segunda Guerra Mundial

\section{Méri Frotscher}

Desde a convocação dos maridos para o front, Magda e muitas outras mulheres casadas tiveram que frequentemente se virar sozinhas para manter a família. O final da guerra e o imediato pós-guerra trouxeram, segundo as sociólogas Sibylle Meyer e Eva Schulze, novos desafios para a capacidade de imposição das mulheres, as quais precisaram utilizar todo o seu talento em organização para obter alimentos para si e a família. As autoras apontam como a superação de exigências extremas aumentou a autonomia e a autoconfiança das mulheres, o que, todavia, muitas vezes levou a conflitos conjugais após o retorno dos maridos. ${ }^{27}$

Onze milhôes de soldados alemães haviam sobrevivido e foram feitos prisioneiros pelos Aliados. Até outono de 1945 cerca de 2,1 milhôes de soldados alemães haviam sido feitos prisioneiros somente pela Uniáo Soviética. No caso de Magda, fazia pouco tempo que o marido havia sido liberado pelos russos e retornado para casa, provavelmente debilitado física e psicologicamente. Segundo o historiador Hans-Ulrich Wehler, durante a guerra imperava um verdadeiro horror entre os soldados alemães de serem feitos prisioneiros pelos soviéti$\cos ^{28}$ Isso porque, nos dois últimos anos da guerra, a propaganda nazista retratava o Exército Vermelho de modo particular "e não de modo totalmente incorreto, como determinado a violentar e a matar os alemães à medida que avançava”. ${ }^{29}$

Depois da guerra, nos primeiros meses após o retorno às suas casas, a maioria dos soldados alemães precisou primeiramente se reestabelecer, em razão dos problemas de saúde e alimentaçáo, ficando temporariamente dependente das mulheres, que se responsabilizavam pelos mantimentos e pelo vestuário. ${ }^{30}$ Este era provavelmente o caso do marido de Magda, que voltara com a amargura da derrota. Com o desfecho da guerra, segundo o historiador Sven Müller, a "estilização do soldado alemão enquanto defensor da pátria" e o "habitus de uma masculinidade heroica" foram abalados. ${ }^{31} \mathrm{~A}$ impotência desses homens diante da derrota era o contraponto da concepção da potência masculina arraigada nas visôes de masculinidade alemãs desenvolvidas, conforme o mesmo autor, já antes do nazismo: "ser 'duro' e 'forte', defender, 'consciente de seus deveres' e 'corajosamente', sua posiçấo na vida e na linha de combate eram grandezas arraigadas no cânone de virtudes da sociedade alemã". 32 Para muitos homens, a derrota e, principalmente, o fato de terem sido feitos prisioneiros de guerra significou um rompimento em suas autoconsciências, segundo apontam Sybille Meyer e Eva Schulze. ${ }^{33}$

\footnotetext{
${ }^{27}$ MEYER, Sibylle; SCHULZE, Eva. "Als wir wieder zusammen waren, ging der Krieg im Kleinen weiter", op. cit., p. 311-312.

${ }^{28}$ WEHLER, Hans-Ulrich. Deutsche Gesellschaftsgeschichte (1914-1949). Bonn: Bundeszentrale für politische Bildung, 2009, p. 943.

${ }^{29}$ EVANS, Richard J. O Terceiro Reich em guerra. 2. ed. Tradução de Lúcia Brito e Solange Pinheiro. São Paulo: Planeta, 2014, p. 644.

${ }^{30}$ MEYER, Sibylle; SCHULZE, Eva. "Als wir wieder zusammen waren, ging der Krieg im Kleinen weiter”, op. cit., p. 315.

${ }^{31}$ MÜLLER, Sven Oliver. Deutsche Soldaten und ihre Feinde: Nationalismus an Front und Heimatfront im Zweiten Weltkrieg. Frankfurt am Main: S. Fischer Verlag, 2007, p. 163.

${ }^{32}$ Ibidem, p. 159.

${ }^{33}$ MEYER, Sibylle; SCHULZE, Eva. "Als wir wieder zusammen waren, ging der Krieg im Kleinen weiter", op. cit., p. 311-312.
} 
"VOU TENTAR AJUdAR MINHA FAMÍLIA ESCREVENDO ESSA CARTA": JOGOS DE GÊNERO EM CARTAS enviadas da Alemanha para o Brasil após a Segunda Guerra Mundial

\section{Méri Frotscher}

É em nome do marido, dela própria e das filhas, que Magda prossegue a redação da carta na primeira pessoa do plural. Ao concluí-la, deseja ao destinatário a graça divina, tal como fez Karoline S. e outros remetentes masculinos e femininos ao final de suas missivas, apelando assim para a caridade cristã: "Nós pedimos ao senhor, do fundo do coração, o envio de um pacote de comida. Que o Senhor Deus lhe traga, por isto, muitos anos de saúde e felicidade." 34

Uma mulher casada que menciona de forma mais explícita sua agência em nome da família é Elisabeth T., refugiada da Prússia Oriental, que escreve o corpo da carta em inglês, acrescentando-lhe um post scriptum em alemão. $\mathrm{Na}$ introdução, ela narra as difíceis condiçôes da fuga, no auge do inverno de 1945, e também as circunstâncias de vida da família enquanto refugiados no centro da Alemanha, onde, segundo ela, muitas pessoas não podiam ou não os tinham ajudado. A seguir, ela expressa sua agência da seguinte forma:

Assim, vou tentar ajudar minha família escrevendo esta carta para o senhor - um estranho para nós - na intenção de lhe implorar que dê esta carta a uma pessoa, família ou comitê que tenha a generosidade de nos assistir em nossas necessidades. Serei grata de todo o coração. Eu espero que o senhor seja amável conosco, nós já sofremos muito. ${ }^{35}$

Em seguida, a autora se desculpa pelo seu inglês, aprendido há muitos anos na escola. Como se percebe, a ajuda esperada é representada enquanto um gesto de generosidade. Assim como na carta de Karoline, ao final da carta de Elisabeth chama atenção a utilização do substantivo "coração" para expressar gratidão antecipada. A palavra "coração" reforça o tom de toda a carta, na qual sentimentos são expressos, apesar do destinatário ser "um estranho". Talvez exatamente por isso, esta e outras mulheres mobilizem sentimentos comumente associados às máes e às mulheres na redação das cartas-pedido como forma de sensibilizar o destinatário. Mais mulheres que homens fazem uso desta palavra, um indício não para uma caracterização de tais sentimentos enquanto "femininos", mas de táticas de sensibilização baseadas em concepçóes sociais do feminino compartilhadas socialmente.

Segundo o historiador Hans-Ulrich Wehler, ao final da guerra, a ausência de 12 milhóes de homens fez com que todo o fardo caísse sobre os ombros das mães e mulheres, sobretudo daquelas que viveram a fuga e a expulsão do Leste da Europa, cujas circunstâncias caóticas teriam causado consequências ainda mais terríveis não fosse o esforço das mulheres e das

\footnotetext{
34 "Wir bitten Sie ans tiefsten Herzen ein Lebensmittelpaket zu schicken. Möge Ihnen dafür der Herrgott lange Jahre Gesundheit und Glück bringen.” Carta de Magda G. Murnau, 20 jul. 1947. Acervo ND.

35 "So I will try to help my family by writing You — a foreigner to us — this letter in the intention to beg You to give my letter to a person, or family, or comitté who will have the kindness to assist us in our need. Of all my heart I will be thankfull to him. I hope You will do the love to us, we have much suffered." Carta de Elisabeth T., Wittinger/Hannover, 14 jun. 1947. Acervo ND.
} 
"VOU TENTAR AJUdAR MINHA FAMÍlIA ESCREVENDO ESSA CARTA": JOGOS DE GÊNERO EM CARTAS enviadas da Alemanha para o Brasil após a Segunda Guerra Mundial

\section{Méri Frotscher}

unidades familiares. ${ }^{36}$ Uma das consequências mais decisivas das perdas ocasionadas pela guerra, segundo o mesmo autor, foi a distribuição desigual dos sexos. Os dados estatísticos de 1950 demonstram que 1.000 homens entre 15 e 65 anos correspondiam a 1.362 mulheres da mesma faixa etária. A diferença numérica entre mulheres e homens era maior ainda na faixa etária entre 25 e 40 anos. ${ }^{37}$

Como as cartas aqui analisadas demonstram, a agência das mulheres em nome das famílias se estende após a guerra. Elisabeth, anteriormente citada, já inicia sua missiva escrevendo em nome da família, utilizando seus parcos conhecimentos de inglês: "Senhor! Muitos alemães têm parentes na América, a quem eles podem escrever uma carta pedindo-lhes ajuda. Meu marido, minha filha de 19 anos, meu filho de 17 e eu não temos nada." ${ }^{38}$ Desta forma, a remetente se coloca como parte de uma família de quatro indivíduos, ordenando por último sua pessoa, apesar de a iniciativa de escrever a carta ter sido sua. A menção dos familiares e a ordenação dos sexos na família são distintas daquelas feitas por Karoline, a autora da epígrafe desse texto, a qual também exerce agência ao pedir auxílio para a família, sem, contudo, nomear o marido.

Outra mulher que escreve em nome da família é Elfriede P., a qual se autodenomina "dona de casa que tem de cuidar de uma família de cinco adultos". ${ }^{39}$ Ela é uma dos remetentes que fez consulta em dados genealógicos para poder "cavar" parentes nas Américas, na esperança de também poder receber CARE package. Ela pede ajuda do prefeito para localizar descendentes de parentes que foram em 1880 para Blumenau, para quem gostaria de pedir pacotes de mantimentos. Elfriede afirma ter se correspondido pela última vez com um dos parentes em 1926, tendo perdido o contato. Muito embora escreva em nome da família, ela mistura as primeiras pessoas do singular e do plural na redação da carta. Não é feita nenhuma menção a um marido no texto.

Não iremos adentrar aqui em todos os casos de agência feminina presentes nas cartas, apenas ainda a redigida por uma jovem solteira, Helga P., pois além de mobilizar uma identidade de gênero, aciona também uma identidade geracional. $O$ fato de morar em Essen, cidade industrial que havia ficado sob a administraçáo inglesa, talvez pudesse explicar o fato de ter escrito em inglês. Contudo, a maioria dos moradores das zonas de ocupaçáo inglesa e norte-americana não escreveu em inglês ao prefeito, mas em alemão. $\mathrm{O}$ fato de ser jovem pode ter facilitado o aprendizado da língua das forças de ocupação. $\mathrm{O}$ imaginário acerca das Américas, de onde se recebiam muitos CARE packages, também poderia tê-la instigado a es-

\footnotetext{
${ }^{36}$ WEHLER, Hans-Ulrich. Deutsche Gesellschaftsgeschichte (1914-1949), op. cit., p. 962.

${ }^{37}$ Ibidem, p. 945.

38 "Sir! Many Germans habe [sic] parents [sic] in America, to whom they can write a letter to ask them for help. My husband, my daughter of nineteenth, my son of seventeenth and I have none." Carta de Elisabeth T., Wittinger/Hannover, 14 jun. 1947. Acervo ND.

${ }^{39}$ Carta traduzida para o português de Elfriede P., Hamburg/Volksdorf, 28 maio 1946. Acervo ND. A tradução foi feita por uma funcionária da Prefeitura Municipal de Blumenau. A carta original não consta no volume de cartas preservado.
} 
"VOU TENTAR AJUdAR MINHA FAMÍlIA ESCREVENDO ESSA CARTA": JOGOS DE GÊNERO EM CARTAS enviadas da Alemanha para o Brasil após a Segunda Guerra Mundial

\section{Méri Frotscher}

crever em inglês. Ela justifica ter tido a ideia de "escrever à América” ("to write to America”) apenas em razão dos sérios problemas circunstanciais. ${ }^{40}$

Seu pedido é elaborado a partir da suposição de que o prefeito comungava com ela certos valores e padróes de vestimenta e de higiene: "Eu tenho 21 anos e perdi a maior parte de meu vestuário e roupa de cama em razão da guerra. Eu penso que o senhor entenderá que uma jovem moça gosta de se vestir de forma asseada e limpa.” ${ }^{41}$ A construção de sua autorrepresentaçáo ocorre não apenas com base em características pessoais e na situação conjuntural em que vivia, mas também no que julgava ser adequado para uma moça de sua classe e gênero. A associação entre o gosto de se vestir "de forma asseada e limpa" e a juventude feminina visa sensibilizar o destinatário. Indiretamente, ela solicita o envio de alimentos, referindo-se à falta de mantimentos, especialmente no Vale do Rio Ruhr, onde morava.

Como podemos perceber nessas cartas enviadas ao prefeito de Blumenau, algumas mulheres casadas exercem a agência feminina por meio do reforço de fronteiras de gênero, enaltecendo a maternidade e outros papéis tradicionalmente associados às mães. Também no caso da moça solteira se associam certas características ao gênero feminino, como asseio e limpeza. Podemos dizer, entáo, que parte das remetentes desenvolve "jogos de gênero" ao elaborarem suas cartas-pedido.

Ao ressaltarmos a agência feminina constante nas cartas, devemos também pensar em que medida ela foi influenciada pelas circunstâncias cotidianas da guerra e do pós-guerra. Segundo Sibylle Meyer e Eva Schulze, baseadas num conjunto de entrevistas feitas com mulheres berlinenses, essa autonomia desenvolvida pelas mulheres em geral não foi almejada ou até mesmo buscada pela maioria delas. No caso daquelas cujos maridos estavam mortos, mutilados ou ainda ausentes por serem prisioneiros de guerra, elas se viam obrigadas a se virar como podiam e a buscar todos os meios possíveis para proverem a família. ${ }^{42}$

A ideologia nacional-socialista havia subordinado a mulher à reivindicação de supremacia masculina, conforme pressupostos racistas e imperialistas. $\mathrm{O}$ culto à maternidade servia aos propósitos de fazer das mulheres máquinas que dariam material humano à nação em expansão. ${ }^{43}$ Mas, como aponta Gisela Bock, a maternidade não era vista como uma limitação para o emprego de mulheres. Tanto o número de mulheres solteiras empregadas, como o de mulheres casadas e de mães aumentou durante o regime nazista. ${ }^{44}$ Como esclarece a autora, "uma parte considerável das políticas nazis a respeito das mulheres tinha por objetivo

\footnotetext{
${ }^{40}$ Carta de Helga P. Essen, 25 abr. 194[?]. Acervo ND.

${ }^{41}$ Idem.

${ }^{42}$ Apud PLATO, Alexander von; LEH, Almut. "Ein unglaublicher Frühling”: Erfahrene Geschichte im Nachkriegsdeutschland 1945-1948, op. cit., p. 51.

${ }^{43}$ GLASER, Hermann. Kleine Kulturgeschichte der Bundesrepublik Deutschland. Munique/Viena: Hanser, 1991, p. 27.

${ }^{44}$ BOCK, Gisela. A política sexual nacional-socialista e a história das mulheres. In: DUBY, Georges; PERROT, Michelle. História das mulheres no Ocidente. Porto: Ediçōes Afrontamento, 1991, p. 196-200.
} 
"VOU TENTAR AJUdAR MINHA FAMÍlIA ESCREVENDO ESSA CARTA": JOGOS DE GÊNERO EM CARTAS enviadas da Alemanha para o Brasil após a Segunda Guerra Mundial

Méri Frotscher

habilitá-las a trabalhar para a família, bem como para o mercado ou para a guerra" ${ }^{45}$ Ideologicamente tais políticas se pautavam na concepção de que a mulher nazi ideal "tinha como primeiro dever servir o Estado, estivesse no emprego ou em casa, em paz ou em guerra". Segundo essa concepção, "qualquer trabalho pesado e 'não feminino', incluindo o trabalho nas fábricas e no campo, desde que para o bem do 'povo', poderia ser exercido pelas mulheres. ${ }^{46}$ Assim, as mulheres participaram ativamente dos esforços de guerra.

Esse papel ativo na esfera da produção, por parte de muitas mulheres, se estendeu depois do colapso, em 1945, quando começou o trabalho de remoção dos escombros. Segundo o historiador Hermann Glaser, "o padrão de organização e da ideologia patriarcal e autoritária havia se quebrado", e os homens, que haviam sido jogados para fora de suas trajetórias de vida em razão da guerra, "estavam moralmente inseguros". ${ }^{47}$

A expressão "Trümmerfrauen", ${ }^{48}$ que se referia às mulheres que participaram da remoção dos escombros, acabou se tornando depois não apenas parte do glossário da história alemã do pós-guerra, como também parte da memória coletiva nacional. Como assinalou o historiador Michel Pollak, acontecimentos, lugares e personagens são elementos constitutivos tanto da memória individual como coletiva ${ }^{49}$ No caso alemão, as "Trümmerfrauen" acabaram tornando-se parte de uma memória nacional alemã construída após a guerra e que remetia à ideia de superação. Nas décadas seguintes, em diversas cidades alemãs chegou-se a erigir monumentos para rememorar ou mesmo glorificar o papel dessas mulheres, constituindo-se, assim, "lugares de memória" 50 materiais para elas.

"Narrar a guerra a partir da perspectiva de gênero", como pleiteia o historiador Luc Capdevila, significa, na interpretação de Joana Maria Pedro, "além de uma inovação na escrita da história, a percepção de identidades sendo constituídas e/ou se dissolvendo". ${ }^{51}$ Autor de estudo sobre a Guerra do Paraguai, Capdevila demonstrou como, apesar da superioridade numérica das mulheres após o desfecho do conflito, não houve uma ruptura, mas um reforço das fronteiras de gênero naquele país. ${ }^{52}$

A historiadora Michelle Perrot adverte para os perigos da ideia generalizada, sobretudo pelo discurso político e pela literatura, de que as guerras mudam radicalmente as relaçóes entre os sexos. A autora sublinha o "caráter espetacular, mas superficial e provisório, das mu-

\footnotetext{
${ }^{45}$ Ibidem, p. 200.

${ }^{46}$ Idem.

${ }^{47}$ GLASER, Hermann. Kleine Kulturgeschichte der Bundesrepublik Deutschland, op. cit., p. 28.

${ }^{48}$ Tradução literal: mulheres dos escombros.

${ }^{49}$ POLLAK, Michel. Memória e identidade social. Estudos Históricos, Rio de Janeiro, v. 5, n. 10, p. 200-2012, 1992.

${ }^{50}$ NORA, Pierre. Entre memória e história. A problemática dos lugares. Projeto História, São Paulo, n. 10, p. 7-28, nov. 1993.

${ }^{51}$ PEDRO, Joana Maria. As guerras na transformação das relaçôes de gênero: entrevista com Luc Capdevila. Estudos Feministas, Florianópolis, v. 13, n. 1, jan./abr. 2005, p. 83.

${ }^{52}$ Ibidem, p. 81-102 e CAPDEVILA, Luc. Una guerra total: Paraguay, 1864-1870: ensaio de historia del tiempo presente. Buenos Aires: Ceaduc/Editorial SB, 2011.
} 
"VOU TENTAR AJUdAR MINHA FAMÍlIA ESCREVENDO ESSA CARTA": JOGOS DE GÊNERO EM CARTAS enviadas da Alemanha para o Brasil após a Segunda Guerra Mundial

\section{Méri Frotscher}

danças ligadas às guerras" - ela se refere às duas guerras mundiais —, que não alteraram verdadeiramente os papéis tradicionais dos sexos, fato que pode ser observado pelo refluxo ocorrido nos momentos do pós-guerra. Contudo, afirma a autora, durante as guerras aumentaria a tensão e as contradiçôes entre os sexos e a consciência que cada um deles tem de si mesmo, o que estimularia, em longo prazo, um feminismo futuro. ${ }^{53}$

Obviamente o pequeno número das cartas aqui analisadas e o fato de terem sido redigidas num curto período de tempo náo possibilitam uma análise das mudanças e/ou permanências nas relaçóes de gênero na Alemanha após a guerra. Entretanto, vale apontar, com base em especialistas na temática, que as circunstâncias da guerra e do imediato pós-guerra não levaram a uma mudança radical nas relaçôes de gênero. Segundo as sociólogas Sybille Meyer e Eva Schulze, a maioria das mulheres ansiava pelo reestabelecimento da tradicional divisão do trabalho no interior da família, em virtude da sobrecarga que recaía sobre elas. Mas o ganho em termos de autonomia e autoconsciência das mulheres foi irreversível. Elas queriam tomar parte nas principais decisóes no espaço da família. ${ }^{54}$ As autoras concluíram que, apesar das mudanças de longa duraçáo em relaçáo ao ganho de autonomia, dos muitos conflitos e separaçôes ocorridos depois da guerra, para a maioria das mulheres a orientação familiar continuou a ser um horizonte. Para os homens, a partir do momento em que se integraram novamente na vida profissional, a família passou para o segundo plano. A ocupação profissional masculina, apesar da ruptura circunstancial havida durante a guerra, quase não teria sofrido transformaçóes na longa duraçáo. Isso só teria ocorrido, como sugerem as autoras, por conta das próprias transformaçóes das esposas e, consequentemente, das estruturas familiares. ${ }^{55}$

Como visto até agora, entre as mulheres houve diferentes formas de se autorrepresentar e escrever, predominando, entre as casadas, que priorizei nessa discussáo, o uso da primeira pessoa do plural ("nós"). Antes de adentrar na análise de cartas de homens, vale lembrar o número de cartas de homens e mulheres e relacionar esses dados e o estado civil às formas de autorrepresentação: 27 cartas foram escritas por homens, 13 por mulheres e uma foi assinada em nome da família. Das seis mulheres que informam serem casadas, nenhuma escreve somente na primeira pessoa do singular ("eu”); uma chega a escrever a carta na íntegra na primeira pessoa do plural ("nós"); cinco misturam ambos os pronomes pessoais ("eu" e "nós")..$^{6}$ À primeira vista, o fato de essas mulheres não escreverem na primeira pessoa do singular poderia parecer natural, afinal, poder-se-ia pensar, eram casadas. O erro da naturalização dessa relação logo se revela ao se comparar tais cartas às dos homens que mencionam serem casados. Muito embora

\footnotetext{
53 PERROT, Michelle. No front dos sexos: um combate duvidoso. In: As mulheres ou os silêncios da história. Tradução de Viviane Ribeiro. Bauru, SP: Edusc, 2005, p. 437 e 446.

${ }^{54}$ MEYER, Sibylle; SCHULZE, Eva. "Als wir wieder zusammen waren, ging der Krieg im Kleinen weiter", op. cit., p. 313-320.

55 Ibidem, p. 322.

${ }^{56}$ Uma carta foi assinada em nome da família e não sabemos se foi escrita por um homem ou uma mulher.
} 
"VOU TENTAR AJUdAR MINHA FAMÍlIA ESCREVENDO ESSA CARTA": JOGOS DE GÊNERO EM CARTAS enviadas da Alemanha para o Brasil após a Segunda Guerra Mundial

\section{Méri Frotscher}

nove escrevam utilizando ora "eu”, ora "nós", quatro escrevem a carta na íntegra na primeira pessoa do singular. Esses últimos, mesmo ao escreverem em nome da família, consciente ou inconscientemente, escrevem enquanto indivíduos, singularizando assim suas existências. Vejamos o exemplo do mestre de obras Franz K., que pede ao prefeito que entregasse a empresas locais as candidaturas a emprego dele próprio e de seus dois filhos adultos:

Em razão das circunstâncias na Alemanha, meu antigo desejo de emigrar para o além-mar novamente passou para o primeiro plano. Mas, infelizmente, para me candidatar a um emprego, me faltam os contatos necessários com a indústria local, ou seja, outras empresas. ${ }^{57}$

Em seguida, o remetente traz dados pessoais — nome, profissão, data de nascimento e ocupações profissionais e períodos respectivos - , tal como era de praxe em candidaturas a emprego.

Mesmo um bancário, que pede mantimentos para a filha, escreve toda a carta na primeira pessoa do singular. Ele pede que a carta fosse encaminhada a uma "família alemã" ou a outro endereço que pudesse enviar mantimentos a uma "pobre criança”, já que não tinha parentes nem conhecidos no exterior:

Como eu, todavia, não tenho tal ligação e minha criança de 7 anos também tem fome e necessita de ajuda, e atestados médicos comprovam [a falta de] óleo de fígado de bacalhau e maltina, coisas que não se obtém em nenhum lugar da cidade, me dirijo ao senhor, prefeito municipal, em minha situação de carestia [....$^{58}$

Em ambos os exemplos citados, contudo, os pais intercedem (também) em nome dos filhos, ou seja, não enquanto pessoas independentes de seus vínculos familiares. Os outros dois pais que escrevem na primeira pessoa do singular, um farmacêutico e um engenheiro civil e de produção, ambos com três filhos, pedem ajuda para emigrar com a família.

Considerando que o termo gênero, segundo Joan Scott, é utilizado para "sugerir que qualquer informação sobre as mulheres é necessariamente informação sobre os homens, que um implica o estudo do outro", ${ }^{59}$ as linhas que seguem se deterão, ainda, na análise de outras cartas escritas por homens, com o intuito de perceber como eles escrevem e como, no caso de algumas das cartas, também se percebem jogos de gênero na argumentação dos pedidos.

\footnotetext{
57 "Durch die Verhältnisse in Deutschland ist mein früheren Wunsch, nach Übersee auszuwandern, wieder in den Vordergrund getreten. Nun fehlen mir leider zur eine Bewerbung um eine Stelle, die erforderlichen Beziehungen zur dortigen Industrie bzw. sonstigen Unternehmungen." Carta de Franz K. Waldalgesheim, 25 mar. 1947. Acervo ND.

58 " $\mathrm{Da}$ ich jedoch keine solche Verbindung habe und mein 7 jähriges Kind aber auch Hunger hat und der Hilfe sehr bedürftig ist, und das beweisen ärztliche Zeugnisse für Lebertran und Malzextrakt, Sachen die man aber in der ganzen Stadt nicht bekommt, so wende ich mich in meiner Notlage an sie Herr Oberbürgermeister [...]." Carta de Ludwig N., Munique, 15 mar. 1947. Acervo ND.

${ }^{59}$ SCOTT, Joan. Gênero: uma categoria útil de análise histórica, op. cit., p. 75.
} 
"VOU TENTAR AJUdAR MINHA FAMÍlIA ESCREVENDO ESSA CARTA": JOGOS DE GÊNERO EM CARTAS enviadas da Alemanha para o Brasil após a Segunda Guerra Mundial

Méri Frotscher

\section{"O que não faz um pai para assegurar o pão de cada dia à sua família?”}

Caso apenas mães fizessem uso da agência para pedir mantimentos, poder-se-ia formular a hipótese de que pudesse parecer vergonhoso e indigno aos pais do sexo masculino pedir ajuda a outro homem. Contudo, há também cartas de homens e é exatamente o uso do papel socialmente reconhecido de pai provedor que fundamenta a escrita das cartas. Willy W., por exemplo, inicia a carta com essa autoidentificação: "Enquanto pai de família, o qual perdeu dois filhos na guerra, me dirijo ao senhor com um grande pedido, um pedido de ajuda para mim e meus familiares. A miséria me obriga a escrever ao senhor." ${ }^{\prime 60}$

A menção à perda dos dois filhos homens reforça o papel que ele próprio se atribui, o de prover a família. Ele não pode mais contar com os filhos homens que morreram, e que poderiam auxiliá-lo nesse papel. Sobre a família não temos mais informaçóes no resto da carta. Mesmo em relação aos filhos mortos, só podemos supor, mas não ter certeza, que haviam morrido enquanto soldados. ${ }^{61}$

Como náo podia contar com a ajuda deles, Willy se dirige ao prefeito de Blumenau, que ele considera provedor de toda uma cidade - ou "colônia", como ele se refere. ${ }^{62}$ Nesta e noutras cartas é possível perceber as relaçôes que os remetentes estabelecem com aquele governante, marcadas por traços de uma cultura política específica na qual a figura de um prefeito - mesmo que desconhecido e governante de uma cidade nunca antes visitada, localizada inclusive fora do país - é concebida enquanto uma autoridade que poderia amparar e prover necessitados. Apesar de (ou exatamente por) serem os remetentes habitantes de localidades que não estavam subordinadas ao mesmo Estado nacional do destinatário, parte deles apelava para a solidariedade étnica — no caso, alemã. Outros apelavam para a caridade e a solidariedade internacional, aquela que não conhece fronteiras nacionais.

Willy W. continua a argumentaçáo explicando a carestia de alimentos vivida pelos habitantes do Erzgebirge, ${ }^{63}$ onde ele e a família moravam. Assim ele descreve essa regiáo montanhosa entre a Saxônia e a Boêmia (República Tcheca), que então fazia parte da zona de ocupação soviética da Alemanha:

Nós moramos na área em estado de emergência da Alta Hercínia, que desde sempre esteve exposta a uma situação alimentar ruim. Aqui só se planta um pouco de aveia e batatas. Em

\footnotetext{
60 "Als Familienvater welcher im Kriege zwei Söhne verloren hat wende ich mich mit einer großen Bitte an Sie, einer Bitte, meinen Angehörigen und mir gütigst zu helfen. Die Not zwingt mich an Ihnen zu schreiben." Carta de Willy W. Annaberg/Erzbebirge, 12 jun. 1947. Acervo ND.

${ }^{61}$ Dos 18,2 milhões de homens alemães convocados para a guerra, 5,32 milhóes morreram. Pelo menos 2/5 dos soldados nascidos entre 1920 e 1925 morreram. WEHLER, Hans-Ulrich. Deutsche Gesellschaftsgeschichte (1914-1949), op. cit., p. 942.

${ }^{62}$ Tanto na carta, como no envelope, o endereçado é a "Administração da cidade - Colônia Blumenau".

${ }^{63}$ Hercínia ou, numa tradução literal, Montes Metalíferos.
} 
"VOU TENTAR AJUdAR MINHA FAMÍlIA ESCREVENDO ESSA CARTA": JOGOS DE GÊNERO EM CARTAS enviadas da Alemanha para o Brasil após a Segunda Guerra Mundial

\section{Méri Frotscher}

consequência da guerra, o estado da alimentação e do vestuário foi tão afetado que nós não sabemos mais o que vamos cozinhar amanhã. Há semanas não temos mais batatas para comer. Por isso eu peço à administração da cidade que não interprete mal o meu pedido, como se ele fosse demais para alguém como eu. $\mathrm{O}$ que não faz um pai para assegurar o pão de cada dia à sua família [?]. Por favor, não deixe que meu pedido se perca sem ter sido ouvido. ${ }^{64}$

A frase interrogativa — "O que não faz um pai para assegurar o pão de cada dia à sua família [?]" - ao mesmo tempo que naturaliza o papel socialmente atribuído ao pai, o de se preocupar com a subsistência da família, também visa justificar e dignificar o pedido ao prefeito. Extintas as possibilidades de prover a família com a ajuda governamental em seu país, ele busca interceder em nome da família junto a uma autoridade no exterior, com base numa estratégia de ação baseada em valores socialmente aceitos para a atuação masculina. Para pais e maridos, quando presentes no cotidiano familiar, a situação de penúria dificultava a satisfação daquele papel social. Nesse aspecto, a narrativa de Willy W. é bem objetiva e direta, e é escrita quase em tom de súplica. Ele associa ao pai o papel de assegurar o "pão de cada dia”, expressão da simbologia cristã presente na oração do Pai-Nosso.

A metáfora do pão para se referir à comida aparece em diversas cartas, tanto de homens como de mulheres. A palavra "pão" compõe algumas palavras na língua alemã e que dizem respeito não apenas à alimentação, mas também a emprego, ocupação ou sustento. ${ }^{65} \mathrm{~A}$ carência alimentícia após a Segunda Guerra Mundial tornou o pão também uma metáfora muito presente na literatura alemã, a qual, devido à singularidade que apresentava, tornou-se conhecida pelas expressões Trümmerliteratur (literatura de escombros) ou Kahlschlagliteratur (literatura de terra arrasada). Nessas obras a fome e o "mercado negro" são temas frequentes. No conto $O$ páo dos anos jovens, do escritor Heinrich Böll, por exemplo, o tema da carência de pão mobiliza uma memória coletiva de fatos vivenciados pelos leitores alemães logo após a guerra ${ }^{66}$ Muito comovente e característico para aquele período de fome é o conto "Das Brot" (O pão), de Wolfgang Borchert, publicado em 1946. ${ }^{67}$ Nele, uma única fatia de pão

\footnotetext{
64 "Wir wohnen in den Notstandsgebiet des Obererzgebirges, welches schon immer einer schlechten Lebensmittellage ausgesetzt gewesen ist. Es wird nur etwas Hafer und Kartoffeln erbaut. Durch die Kriegseinwirkung ist die Ernährungs- und Bekleidungslage so in Mittleidenschaft gezogen worden, da $\beta$ wir nicht mehr wissen was wir morgen kochen. Seit Wochen haben wir keinen Kartoffel zuessen. Ich bitte daher der Stadtverwaltung meine Bitte, uns zuhelfen nicht vermessen erscheinen zu lassen. Was macht nicht ein Vater um das tägliche Brot für seine Familie sicher zustellen [?]. Bitte lassen Sie meine Bitte nicht ungehört verhallen.” Carta de Willy W. Annaberg/ Erzgebirge, 12 jun. 1947. Acervo ND.

${ }^{65}$ Como exemplos temos as palavras Broterwerb (trabalho exercido para o sustento), brotlos (sem trabalho que permita o sustento), Brotherr/Brotgeber (patrão), Brotberuf (profissão exercida não por afeição, mas para garantir o sustento). Disponível em: <http://www.duden.de/suchen/dudenonline/Brot\%20>. Acesso em: 15 mar. 2016. ${ }^{66}$ SCHMITT, Elise. Literatura alemã pós-guerra. O Grupo 47 e a representação social em Heinrich Böll e Günter Eich. Saarbrücken: Novas Ediçóes Acadêmicas, 2014, p. 116-119.

${ }^{67}$ Ele mesmo sofria de doença no fígado, em consequência da desnutriçáo e da falta de atendimento médico durante a guerra, vindo a falecer em novembro de 1947.
} 
"VOU TENTAR AJUdAR MINHA FAMÍLIA ESCREVENDO ESSA CARTA": JOGOS DE GÊNERO EM CARTAS enviadas da Alemanha para o Brasil após a Segunda Guerra Mundial

\section{Méri Frotscher}

funciona como símbolo da fome vivenciada no cotidiano de um casal e torna-se motivo para tratar da relação entre marido e mulher naquele período crítico de carestia.

O papel do pai enquanto provedor da família e que procura exercer essa função por meio do trabalho aparece também na carta do operário Wilhelm M. Já no início da carta, ele se representa enquanto "trabalhador alemão" e menciona os moradores "ex-alemães" de Blumenau para, mais adiante, falar da carestia e do difícil papel de prover a família:

$\mathrm{Eu}$, trabalhador alemão, me dirijo ao senhor, aos seus funcionários e aos então alemães que aí vivem na felicidade e no sossego, com o pedido de que enviem um pequeno donativo a mim e a minha família, pois aqui na Alemanha reina grande pobreza. A todos falta vestuário e comida. Aqui se vive grande carência com a família. Se perdeu tudo com a guerra. Não é fácil quando se precisa mendigar, mas o que não se faz tudo pelas crianças, mas a necessidade me obriga. ${ }^{68}$

Não há informaçôes sobre o tamanho da família na carta-pedido, cuja trama apresenta o jogo de opostos "trabalhador" x "mendigo". A autorrepresentaçáo "trabalhador alemáo", ao mesmo tempo em que assegura a dignidade do peticionário, visa desfazer possível má impressão. Ele acentua que, apesar de ter uma ocupação profissional, a "grande pobreza" que "reina(va)" em todo o país o obrigaria a "mendigar" em nome da família. Nessa e noutras cartas, também de mulheres, os motivos dados para os pedidos são as circunstâncias causadas por razões alheias às suas vontades. A guerra - e suas consequências - é o agente de todas as perdas e o motivo para que ele "mendigasse" em nome dos filhos. Não é uma condição, ele explica, mas uma situação excepcional, uma "emergência". Por isso ele apela para os "ex-alemães" de Blumenau que viveriam, segundo ele, "na felicidade e sorte e no sossego". Apesar da associação que ele estabelece entre aqueles afortunados e ele próprio, Wilhelm traça uma diferença material circunstancial: o fato de aqueles não terem sofrido diretamente perdas em razão da guerra e viverem a carestia que ora se enfrentava na Alemanha.

A narrativa mais uma vez deixa perceber — na frase "Mas não é fácil ter que mendigar" - questôes que relacionam masculinidade e o que a sociedade esperava de um pai. Afinal, "mendigar", mesmo sendo um trabalhador, lhe parecia um ato tâo indigno que somente aquela situação de "emergência" e em favor dos filhos poderia obrigá-lo a fazê-lo.

Em que pese a agência desse sujeito, exercida por meio da escrita da carta-pedido, ele se representa como parte de um todo, uma comunidade nacional, daí a autoidentificação "trabalhador alemáo". Esse adjetivo e também a frase que dá sequência à carta demonstram

68 "Ich als Deutscher Arbeiter trete mit der Bitte an Sie heran bei Ihren Angestellten und den ehemaligen Deutschen die dort bei Ihnen in Glück und Zufriedenheit leben, für mich und meine Familie zuwerben um eine kleine Gabe, denn hier bei uns in Deutschland herrscht grosse Armut. Es fehlt an allen an Kleidung und Lebensmittel. Man lebt mit der Familie in grosser Not. Man hat durch den Krieg alles verloren. Es ist nicht leicht, wenn man betteln gehen muss, aber was tut man nicht alles für die Kinder, aber die Not zwingt einen." Carta de Wilhelm M. Veltheim, 16 mar. 1947. Acervo ND. 
"VOU TENTAR AJUdAR MINHA FAMÍLIA ESCREVENDO ESSA CARTA": JOGOS DE GÊNERO EM CARTAS enviadas da Alemanha para o Brasil após a Segunda Guerra Mundial

\section{Méri Frotscher}

como o remetente busca mobilizar uma suposta identidade étnico-nacional de parte dos "alemães" de Blumenau: "Então eu peço ao senhor que intervenha entre seus funcionários e ex-alemães em favor de uma pequena doação. Eu apelo ao senso de justiça que entre vós impera para amenizar a carestia no mundo." Em três momentos da carta estáo presentes o adjetivo "alemão" e o substantivo "alemães", o que revela a tentativa de mobilização de solidariedade étnica, tal como outros remetentes procuraram fazê-lo em seus apelos. ${ }^{69}$

Pedir ajuda para alguém desconhecido poderia quebrar o padráo socialmente aceito da autonomia socioeconômica da família. Por isso, muitos remetentes julgam necessário justificar a situação emergencial em que se encontrava a família e o país, como na carta já mencionada (“A emergência obriga”). Não se trata, porém, de pedir a qualquer pessoa, mas à autoridade máxima de um município que tinha laços histórico-culturais com o país dos remetentes.

Diversas cartas demonstram que a tentativa de mobilização de identidades de gênero se dava simultaneamente à mobilização de solidariedades étnicas, geracionais, de classe, profissionais e, até mesmo, regionais. Em relação à variável classe e profissão, citamos a carta do bancário Ludwig N., que intercede também em nome da família. Sua redação é mais rebuscada do que a de trabalhadores ou agricultores. $\mathrm{O}$ pedido de donativos vem justificado por meio de uma análise das diferentes condições de vida e de acesso à assistência social entre os alemães. Esse pai intervém em forma de apelo principalmente em nome da filha:

Os abastados se viram nessa época difícil comprando no "mercado negro" e as famílias pobres com muitos filhos são, em parte, assistidas pelas organizações de ajuda estabelecidas em algumas localidades. A classe média não pode nem comprar no mercado negro nem é considerada pelas organizaçóes em prol do bem-estar. Outros têm amigos ou parentes no exterior e são, dessa parte, abastecidos de forma suplementar. ${ }^{70}$

$\mathrm{Na}$ carta, fica claro como questóes de classe determinavam também o acesso a recursos no imediato pós-guerra. Ludwig N., excluído das possibilidades mencionadas de obter ajuda, narra como era difícil prover a família. Ele é um dos poucos pais que se refere à saúde da filha. Mais do que os homens, as mulheres se referem também, por vezes, a problemas de saúde e educação dos filhos.

Alguns escreventes não tinham sequer emprego ao qual pudessem se remeter em suas cartas, que expressam com dramaticidade sua situação. $\mathrm{O}$ trabalho é entendido não apenas

${ }^{69}$ Sobre este aspecto, vide artigo já publicado, baseado no mesmo conjunto documental. FROTSCHER, Méri. "A miséria me obriga a escrever ao senhor": a escrita de si em cartas de alemães ao prefeito de Blumenau-SC (1946-1948).

70 "Die Begüteter helfen sich über die schwere Zeit durch Kauf auf dem 'Schwarzen Markt' zu hinweg und die mindertermittelten kinderreichen Familien werden zum Teil von den mancherorts eingesetzten Hilfsorganisationen betreut. Der Mittelstand kann weder das erstere tun, noch wird er von den Wohlfahrtseinrichtungen berücksichtigt. Andere wieder haben Freunde oder Verwandte im Auslande und werden dann von dieser Seite zusätzlich versorgt." Carta de Ludwig N., Munique, 15 mar. 1947. Acervo ND. 
"VOU TENTAR AJUdAR MINHA FAMÍlIA ESCREVENDO ESSA CARTA": JOGOS DE GÊNERO EM CARTAS enviadas da Alemanha para o Brasil após a Segunda Guerra Mundial

\section{Méri Frotscher}

enquanto meio de sustento, mas também enquanto um valor que confere dignidade ao homem. Era o caso de refugiados como Albert D., o qual se identifica como "refugiado expulso da Prússia Oriental”. Ele assume o papel de pai responsável pelo abastecimento da família, o qual, diante da inevitabilidade da miséria imposta pelas circunstâncias, tem de apelar para a ajuda alheia. Na carta ele menciona sua condição de refugiado, as condiçóes dramáticas vividas pela família e seus esforços em lutar por recursos. Segundo ele, por terem sido agricultores e depois expulsos, perderam não só a propriedade e a pátria, mas também a própria "existência". Assim, para ele, viver sem poder trabalhar seria como perder a existência. Essa concepção foi elaborada ao longo da história, como sublinhou a filósofa Hannah Arendt: "A era moderna trouxe consigo a glorificação teórica do trabalho, e resultou na transformação efetiva de toda a sociedade em uma sociedade do trabalho." ${ }^{71}$ A perda da propriedade rural e o deslocamento para um contexto urbano, antes desconhecido, tornava muito mais difícil a tarefa de sustentar uma família, num país onde mesmo os que residiam há muito tempo num lugar não tinham recursos suficientes.

Depois de informar a composição da família e a idade dos filhos, de 12, 15 e 19 anos, todos sem ganho, Albert apela ao prefeito, em tom de desespero:

Preciso cuidar de todos e não sei de onde tirar. Nesse estado de extrema miséria eu peço, senhor prefeito, me ajude o mais breve possível, não há aqui como escapar dessa grande miséria. Eu asseguro que nem recebo salário nem possuo bens e que, para a subsistência da minha família, eu preciso brigar pelos parcos recursos da assistência social. Sem trabalho, sem salário, me tornei um inválido recebedor de esmolas. ${ }^{72}$

Também na narrativa dessa carta perpassa o sentimento de impotência diante das dificuldades, perdas e falta de perspectivas de melhoria das condiçóes de vida e trabalho, assim como o ressentimento por não poder sustentar a si e a sua família.

Já um idoso de 78 anos, August A., escreve em nome de toda a família, não apenas esposa e filhos, mas também das famílias de seus filhos. Escreve, portanto, enquanto uma espécie de "patriarca" de uma família de sete pessoas, contando ele próprio, a esposa, a filha e o filho dela - o genro havia "tombado" na Rússia — além do filho, da esposa e do(a) filho(a) dele, apesar de esses últimos morarem noutro domicílio. Mesmo representando a si próprio e sua esposa, de 70 anos, como "pessoas idosas e frágeis", ${ }^{73}$ ele exerce agência se colocando no pa-

\footnotetext{
${ }^{71}$ ARENDT, Hannah. A condição humana. 4. ed. Rio de Janeiro: Forense-Universitária, 1989, p. 12.

72 "Für alle muss ich sorgen und ich weiss nicht woher ich nehmen soll. In dieser äussersten Not bitte ich Sie, Herr Bürgermeister, helfen Sie bitte bald, es gibt hier kein Entrinnen aus der grossen Not. Ich versichere, dass ich weder Einkommen noch Vermögen besitzte und meinen Lebensunterhalt für meine Familie aus den kargen Mitteln der Fürsorgenunterstützung bestreiten muss. Ohne Arbeit, ohne Verdienst, ein entkräfteter Almosenempfänger bin ich geworden." Carta de Albert D., Thaden (Schleswig-Hollstein), 12 fev. 1947. Acervo ND. ${ }^{73}$ Carta de August A., Duisburg/Hamborn am Rhein, 30 maio 1947. Acervo ND.
} 
"VOU TENTAR AJUdAR MINHA FAMÍlIA ESCREVENDO ESSA CARTA": JOGOS DE GÊNERO EM CARTAS enviadas da Alemanha para o Brasil após a Segunda Guerra Mundial

\section{Méri Frotscher}

pel de líder daquela família. Mobiliza, portanto, também uma identidade geracional, aqui associada não somente à idade, mas também à fragilidade. Na carta, ele lista os alimentos que mais faltavam à populaçáo do Vale do Rio Ruhr, onde morava com a família. Assim, ele também se posiciona não apenas enquanto um indivíduo e um "chefe de família", mas também enquanto membro de toda uma região afetada seriamente pela guerra. Além dos alimentos, ainda cita tabaco, então supervalorizado em razão do seu valor de troca.

Em cartas de homens solteiros (ou de pessoas que não mencionam cônjuges e filhos), observam-se também, muito embora menos, questóes de gênero implícitas na forma como se autorrepresentam ou se dirigem ao destinatário. ${ }^{74}$ Cito a de um jovem técnico em montagem de máquinas têxteis da Saxônia que se dirige ao prefeito de Blumenau com a intenção de trabalhar no parque industrial têxtil. A falta de perspectivas de trabalho e de formação profissional e também as perdas sofridas durante a guerra - os dois pais morreram durante um bombardeio e ele perdeu sua mão direita quando servia enquanto soldado - fazem Heinz R. ressaltar suas habilidades técnicas. Elas são detalhadas no currículo que ele envia em anexo. Como outros que expressavam o desejo de emigrar, sua autorrepresentação acentua a identidade de trabalhador. $\mathrm{O}$ corpo mutilado provavelmente o incapacitava para certas funçôes, daí acentuar seus conhecimentos técnicos e expressar o desejo de "servir" ao Brasil "por meio do meu trabalho" 75 Aqui é visível não apenas a expressão de obediência, mas a militarizaçáo do trabalho. Durante o nacional-socialismo, a obediência foi um dos valores transmitidos à juventude masculina em todas as instâncias de socialização do regime, com o intuito de fazer dos homens "lutadores" alemães. ${ }^{76} \mathrm{O}$ uso do verbo "servir", próprio também do campo militar, no qual ele havia se socializado durante a guerra, expressa a militarização dos corpos masculinos e da própria linguagem. Se antes ele colocara seu corpo à disposiçâo da nação, com o retorno à vida civil e a expectativa de uma emigração futura, mostra-se disposto a "servir" ao Brasil por meio do trabalho, ou seja, a ser um soldado do trabalho.

Tanto cartas de homens como de mulheres priorizam o pedido de mantimentos. Somente homens, é certo que poucos, pedem tabaco, o que se explica pela associação então naturalizada entre consumo de tabaco e masculinidade e, sobretudo, pelo valor deste produto no "mercado negro". Outros remetentes pedem empregos e/ou informaçóes que pudessem ajudá-los a se decidir em prol de uma emigração futura. Mais homens que mulheres pedem a mediação da prefeitura para obter endereços de pessoas com as quais pudessem iniciar correspondência. Todos esses aspectos demonstram como a própria natureza dos pedidos pode guardar relações com questôes de gênero, não entendido aqui enquanto uma naturalização, mas enquanto resultado de diferentes processos de socialização.

\footnotetext{
${ }^{74}$ Carta de Heinz R., Chemnitz, 20 mar. 1947. Acervo ND.

75 Idem.

${ }^{76}$ MÜLLER, Sven Oliver. Deutsche Soldaten und ihre Feinde: Nationalismus an Front und Heimatfront im Zweiten Weltkrieg, op. cit., p. 158.
} 
"VOU TENTAR AJUdAR MINHA FAMÍlIA ESCREVENDO ESSA CARTA": JOGOS DE GÊNERO EM CARTAS enviadas da Alemanha para o Brasil após a Segunda Guerra Mundial

Méri Frotscher

\section{Considerações finais}

O escritor Walter Kempowski, num dos romances que compóem a chamada "Deutsche Chronik" (Crônica Alemã), série na qual mistura ficção e elementos da história de sua própria família, menciona a tática utilizada por muitos alemães, após a Segunda Guerra Mundial, de localizar e enviar correspondências a parentes no exterior que pudessem lhes encaminhar pacotes de mantimentos. Assim ele escreve: "Diz-se, em toda parte agora são 'escavados' tias e tios no exterior, para os quais se escrevem afetuosas cartas. Trata-se de sobreviver." 77

Muitos dos remetentes das cartas analisadas neste artigo parecem ter sido movidos a escrever ao verem outras pessoas receberem pacotes do exterior. A maioria, contudo, não tinha parentes ou amigos que pudessem ser "escavados" no exterior. Eles buscam entáo sensibilizar a administração de uma cidade reconhecida como uma ex-colônia fundada por imigrantes alemães no Brasil, por meio da descrição da carência material e das perdas ocorridas durante a guerra. As circunstâncias materiais vividas na Alemanha no pós-guerra são a principal justificativa para os pedidos de mantimentos, informaçôes e intermediaçôes com habitantes da cidade. O acento no caráter "emergencial" dá o tom dos apelos presentes nas missivas e visa garantir a dignidade dos remetentes. Recorrer a um prefeito de uma cidade conhecida apenas por meio de livros e relatos parecia ser uma alternativa às dificuldades de acesso a mantimentos na Alemanha.

Como procurei demonstrar, diversos remetentes se utilizaram de papéis de gênero reconhecidos socialmente ao escreverem suas cartas-pedido, reforçando o que era considerado próprio "do masculino" ou "do feminino" ou do ser pai ou mãe. As cartas também contêm uma dimensão performática e seus remetentes recorrem a discursos normativos que dizem respeito a questôes de gênero para se autorrepresentar e/ou para se tecer a relaçáo com o destinatário. Como também observou Marilda Ionta, nesse tipo de escrita de si podem se delinear "performances que reforçam as identidades e os papéis que a sociedade reservou a cada gênero". 78

Muito embora as cartas tenham cruzado o Atlântico e, assim, adentrado um espaço geográfico e sócio-histórico distinto, seus remetentes "jogam” com identidades de gênero que, como se pressupunha, eram similares na sociedade de destino. Elas traduzem agências femininas e masculinas transatlânticas, redigidas num espaço nacional abalado pelas cir-

77 “Überall würden jetzt Tanten und Onkels im Ausland ausgegraben, denen würde liebevoll geschrieben. Es gehe eben ums Überleben.” KEMPOWSKI, Walter. Uns geht's ja noch gold: Roman einer Familie. 5. Auflage. Munique: Taschenbuch Verlag, 1978, p. 287.

${ }^{78}$ IONTA, Marilda. Cartas de pijama: amizade e relaçóes de gênero na correspondência de Márcio de Andrade e Anita Malfati. In: BASTOS, Maria Helena Camara; CUNHA, Maria Teresa Santos; MIGNOT, Ana Chrystina Venancio. (Org.). Destinos das letras: história, educação e escrita epistolar. Passo Fundo: Editora UPF, 2002, p. 254. 
"VOU TENTAR AJUdAR MINHA FAMÍlIA ESCREVENDO ESSA CARTA": JOGOS DE GÊNERO EM CARTAS enviadas da Alemanha para o Brasil após a Segunda Guerra Mundial

Méri Frotscher

cunstâncias econômicas, políticas e morais de um país derrotado, agora ocupado pelas forças militares dos países vencedores. É, assim, por sobre as fronteiras desse espaço nacional em crise que os remetentes elaboram suas cartas-pedido àquele destinatário no Brasil, naturalizado como uma autoridade política masculina.

\section{Referências bibliográficas}

ARENDT, Hannah. A condição humana. 4. ed. Rio de Janeiro: Forense Universitária, 1989. BOCK, Gisela. A política sexual nacional-socialista e a história das mulheres. In: DUBY, Georges; PERROT, Michelle. História das mulheres no Ocidente. Porto: Ediçôes Afrontamento, 1991, p. 185-219.

CAPDEVILA, Luc. Résistance civile et jeux de genre. France-Allemagne-Bolivie-Argentine. Deuxième Guerre monciale — années 1970-1980. Annales de Bretagne et de Pays de l'Quest, t. 108, n. 2, p. 103-128, 2001.

. Uma guerra total: Paraguay, 1864-1870. Ensayo de historia del tiempo presente. Buenos Aires: Editorial Sb, 2010.

EVANS, Richard J. O Terceiro Reich em guerra. 2. ed. Tradução de Lúcia Brito e Solange Pinheiro. São Paulo: Planeta, 2014.

FERNANDES, Evandro. S.O.S. Europa faminta: Comitê de Socorro à Europa Faminta - SEF. Florianópolis, 2005, 177f. Dissertação (Mestrado em História) - Universidade Federal de Santa Catarina, Florianópolis, 2005.

. Organização e articulação do Comitê de Socorro à Europa Faminta — SEF (19461949). História Unisinos, v. 17, n. 2, p. 97-111, 2013.

FOUCAULT, Michel. A escrita de si. . O que é um autor? Lisboa: Passagens. 1992.

FROTSCHER, Méri. “Uma cinzenta falta de esperança paira sobre todos nós”: Uma análise de cartas de mulheres e homens com intenção de emigrar da Alemanha para o Brasil (1946-1950). Revista de História, Sáo Paulo, n. 117, p. 1-38, 2018. Disponível em: <http://www. revistas.usp.br/revhistoria/article/view/138467/139822>.

. "A miséria me obriga a escrever ao senhor": a escrita de si em cartas de alemães ao prefeito de Blumenau-SC (1946-1948). Tempo e Argumento, Florianópolis, v. 7, n. 15, p. 137-176, maio/ago. 2015.

GLASER, Hermann. Kleine Kulturgeschichte der Bundesrepublik Deutschland. Munique/ Viena: Hanser, 1991.

GOMES, Angela de Castro (Org.). Escrita de si, escrita da história. Rio de Janeiro: Editora Fundação Getulio Vargas, 2004. 
"VOU TENTAR AJUdAR MINHA FAMÍlIA ESCREVENDO ESSA CARTA": JOGOS DE GÊNERO EM CARTAS enviadas da Alemanha para o Brasil após a Segunda Guerra Mundial

IONTA, Marilda. Cartas de pijama: amizade e relaçóes de gênero na correspondência de Márcio de Andrade e Anita Malfati. In: BASTOS, Maria Helena C.; CUNHA, Maria Teresa S.; MIGNOT, Ana Chrystina V. (Org.). Destinos das letras: história, educação e escrita epistolar. Passo Fundo: Editora UPF, 2002, p. 243-263.

KEMPOWSKI, Walter. Uns geht's ja noch gold: Roman einer Familie. 5. Auflage. Munique: Taschenbuch Verlag, 1978.

LIMA, Kleverson Teodoro de. Cartas, história e linguagem. Revista de Teoria da História, ano 1, n. 3, p. 210-225, jun. 2010.

MAHMOOD, Saba. Teoria feminista, agência e sujeito liberatório. Algumas reflexôes sobre o revivalismo islâmico no Egipto. Etnográfica, v. 10, n. 1, p. 121-158, 2006.

MALATIAN, Teresa. Cartas. Narrador, registro e arquivo. In: PINSKY, Carla B.; LUCA, Tania R. de (Org.). O historiador e suas fontes. São Paulo: Contexto, 2011, p. 195-221.

MEYER, Sibylle; SCHULZE, Eva. "Als wir wieder zusammen waren, ging der Krieg im Kleinen weiter". Frauen, Männer umd Familien in Berlin der vierziger Jahre. In: NIETHAMMER, Lutz; PLATO, Alexander von. "Wir kriegen jetzt andere Zeiten". Auf der Suche nach der Erfahrung des Volkes in nachfaschistischen Ländern. Berlim/Bonn: Verlag J. H. W. Dietz, 1985, p. 305-326.

MÜLLER, Sven Oliver. Deutsche Soldaten und ihre Feinde: Nationalismus an Front und Heimatfront im Zweiten Weltkrieg. Frankfurt am Main: S. Fischer Verlag, 2007.

NORA, Pierre. Entre memória e história. A problemática dos lugares. Projeto História, São Paulo, n. 10, p. 7-28, nov. 1993.

PEDRO, Joana Maria. As guerras na transformação das relações de gênero: entrevista com Luc Capdevila. Estudos Feministas, Florianópolis, v. 13, n. 1, p. 81-102, jan./abr. 2005.

PEDRO, Joana Maria; PEREIRA, Silvana Maria; VENSON, Anamaria Marcon. Para além das áreas do conhecimento definidas: relações de gênero e interdisciplinaridade. In: CRESCÊNCIO, Cíntia Lima; SILVA, Janine Gomes da; Lídia Schneider Bristot (Org.). Histórias de gênero. São Paulo: Verona, 2017, p. 26, p. 14-31.

PERROT, Michelle. Introdução. In: (Org.). História da vida privada. Da Revolução Francesa à Primeira Guerra. Tradução de Denise Bottman e Bernardo Joffily. São Paulo: Companhia das Letras, 1991, v. 4.

. No front dos sexos: um combate duvidoso. In: . As mulheres ou os silêncios da história. Tradução de Viviane Ribeiro. Bauru, SP: Edusc, 2005, p. 435-446.

PLATO, Alexander von; LEH, Almut. "Ein unglaublicher Frühling": Erfahrene Geschichte im Nachkriegsdeutschland 1945-1948. Bonn: Bundeszentrale für politische Bildung, 1997. POLLAK, Michel. Memória e identidade social. Estudos Históricos, Rio de Janeiro, v. 5, n. 10, p. 200-2012, 1992. 
SCHMITT, Elise. Literatura alemã pós-guerra. O Grupo 47 e a representação social em Heinrich Böll e Günter Eich. Saarbrücken: Novas Ediçôes Acadêmicas, 2014.

SCOTT, Joan. Gênero: uma categoria útil de análise histórica. Educação e Realidade, Porto Alegre, v. 20, n. 2, p. 71-99, 1995.

WEHLER, Hans-Ulrich. Deutsche Gesellschaftsgeschichte (1914-1949). Bonn: Bundeszentrale für politische Bildung, 2009.

WENDT, Bernd Jürgen. Das nationalsozialistische Deutschland. Berlim: Landeszentrale für politische Bildungsarbeit Berlin, 1999. 